\title{
Organic matter in coal seam-VI of the Barapukuria coal field in Bangladesh
}

\author{
S. Tahsin ${ }^{1}$, H. M. Z. Hossain ${ }^{1,2 *}$ and M. M. Hossain ${ }^{3}$ \\ ${ }^{1}$ Department of Petroleum and Mining Engineering, Jessore University of Science and Technology, Jessore-7408, \\ Bangladesh \\ ${ }^{2}$ Atmosphere and Ocean Research Institute, the University of Tokyo, Chiba 277-8564, Japan \\ ${ }^{3}$ Barapukuria Coal Mining Company Limited (BCMCL), Dinajpur, Bangladesh
}

\begin{abstract}
Organic matter sources and depositional environments of Permian Gondwana coals in the coal seam-VI, Barapukuria coal field, northwestern Bangladesh have been investigated using CHNS elemental analysis. A total of 8 coal samples were collected from the coal seam-VI within depth range between 118 and $509 \mathrm{~m}$. Total organic carbon (TOC), hydrogen, nitrogen and sulfur contents range from 48 to 75 (average 61 wt.\%), 3.89 to 5.80 (average 4.59 wt.\%), 2.87 to 3.87 (average 3.28 wt.\%), and 0.19 to 0.37 wt.\% (average 0.30 wt.\%), respectively. C/N ratio range between 14 and 21 (average 19), and a positive correlation between TOC and TN $(r=0.51)$ suggested that organic matter in the coals was derived largely from terrestrial plants. However, C/S ratio values (up to 376) and scatter distribution between TOC and TS indicates the coal seam-VI was deposited in fresh water dominated inland lake environments.
\end{abstract}

Keywords: Organic matter; Depositional environment; Gondwana coal; Barapukuria coal field; Bangladesh.

\section{Introduction}

Coal is one of the most important and relatively inexpensive energy resources around the globe. Bangladesh has enormous coal reserves, most of these coal deposits located in the northwestern part of the country (Fig. 1). The major coal deposits of Bangladesh as well as adjacent Indian landmass occur in Permian Gondwana sequences. The Gondwana coal in Bangladesh has been identified in the vicinity of Barapukuria, Khalaspir, Dighipara, Phulbari and Jamalganj (Fig. 2a) and it occurs mostly at shallow depths (Fig. 2b). The Barapukuria coal field is the first major coalfields in Bangladesh, which discovered in 1985 by Geological Survey of Bangladesh (GSB). The Gondwana Barapukuria coal basin islocated in the Parbatipur thana of Dinajpur district, which is close to the West Bengal of India (Fig. 1). The basin covers an area of approximately $5.25 \mathrm{~km}^{2}$ (WardellArmstrong, 1991). Coal in this coal field is encountered at a depth range between 195 and $535 \mathrm{~m}$ from the surface (Bakr et al., 1996; Hossain et al., 2013a). The estimated coal reserve of the Barapukuria coal field is about 390 million tons (Imam, 2013). Six major coal seams of different thickness were identified in the basin, and coal seam-VI alone represents approximately $36 \mathrm{~m}$ (Norman, 1992; Bakr et al., 1996). The coals are mainly high volatile sub-bituminous to bituminous rank (Bakr et al., 1996; Imam, 2013). This coal was deposited in cool climatic conditions during the Permian period (Wardell-Armstrong, 1991).

Several authors have been investigated in this coal-bearing Gondwana sequence, Barapukuria basin atdifferent points of view (Norman, 1992; Hussain and Curtin, 1995; Bakr et al., 1996; Islam et al., 2003; Islam and Hossain, 2006; Islam and Hayashi, 2008; Farhaduzzaman et al., 2012; Hossain et al., $2013 a, b)$. However, investigation of organic matter source and depositional environment in Barapukuria coal using CHNS elemental analyses has not been quantified. The main objective of this study is to provide the results of organic geochemical analyses, in order to compare these coals in terms of organic matter composition, source and environment of deposition in the coal-bearing Barapukuria basin, northwestern Bangladesh. The results obtained will also be compared with similar studies of Gondwana coals from neighboring countries.

*Corresponding author. e-mail: zakirgsd@yahoo.com 


\section{Geological setting}

The Bengal Basin is situated in the northeastern part of the Indian sub-continent occupying whole Bangladesh, Assam, Tripura, Myanmar and part of the Bay of Bengal (Fig. 1). The Barapukuria coal field is placed in the north western part of Bangladesh, which was primarily joined with Precambrian Indian landmass, South Africa, Antarctica and Australia building an extensive continental landmass named Gondwanaland (Imam, 2013). This coal is also called Gondwana coal because it was deposited within the Gondwana Supergroup. The coal in the basin was formed by the geologic processes of burial forest debris during the
Permian ( 250 million years) and coalification of buried organic matter by subsurface heat and pressure (Imam, 2013). The Barapukuria basin comprises an elongated asymmetrically half-graben type (Fig. 2, Norman, 1992), is thus equivalent to the Gondwana basins in India (Ward, 1984; Mishra, 1996), consists mainly of Precambrian Basement Complex, Early Permian GondwanaGroup, Late Miocene to Middle Pliocene Dupi Tila Formation, Late Pliocene to Pleistocene Barind Clay Formation and recent alluvium in an ascending order (Wardell-Armstrong, 1991). Stratigraphy of the Gondwana succession in the Barapukuria basin is summarized in Table I and Fig. 3.

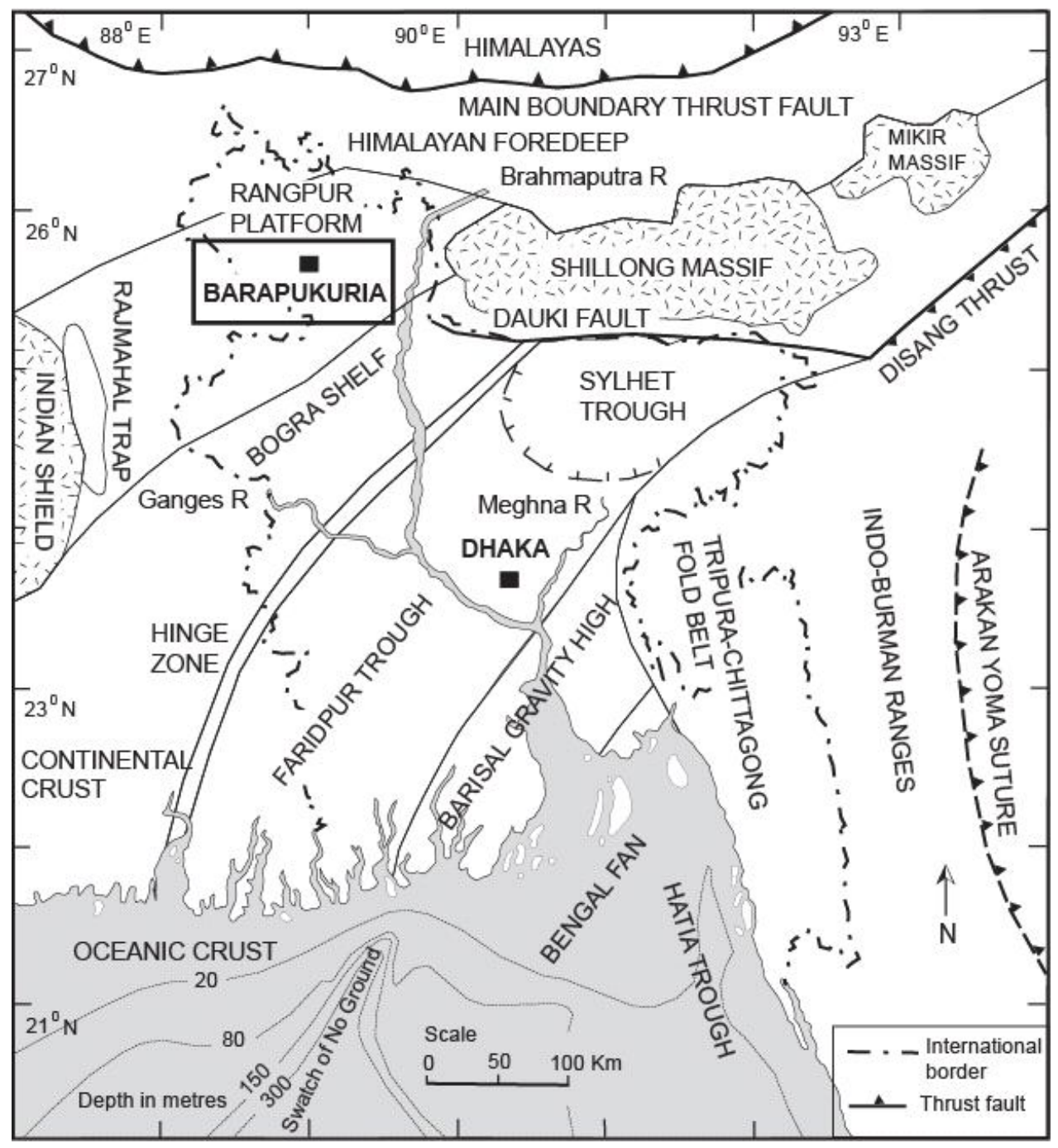

Fig. 1. Generalized map showing location of the Barapukuria coal field and major physiographic and geotectonic features of the Bengal Basin and adjoining areas (modified after Hossain et al., 2013a) 

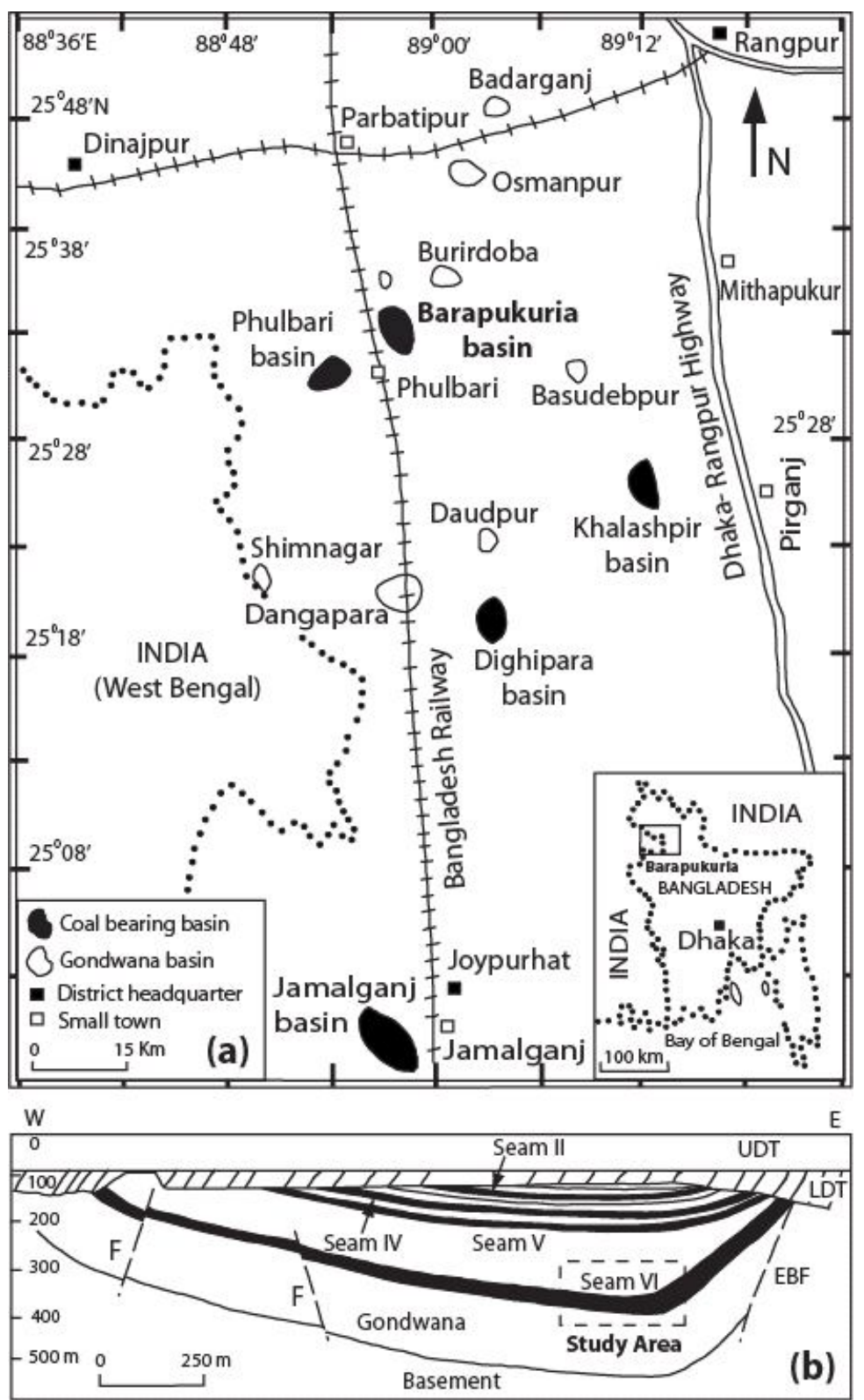

Fig. 2(a). Map showing the sampling site and distribution of major coal fields in northwestern Bangladesh (modified after Islam and Hayashi, 2008, Farhaduzzaman et al., 2012), and (b) East-west crustal cross-section through the Barapukuria basin, northwestern Bangladesh (modified after Norman, 1992)

The Precambrian rocks from the basement of all geological formations referred to as a Basement Complex, consists mainly of granite, granodiorite, diorite and gneiss (Hussain and Curtin, 1995; Bakr et al., 1996). The oldest sedimentary rock unit in Bangladesh is the Lower Gondwana Group of Permian age which unconformably overlies the Basement Complex (Fig. 3 and Table I). It is composed predominantly of feldspathic sandstone, carbonaceous sandstone, siltstone, shale with thick to thin coal seams and occasionally conglomerate (Bakr et al., 1996; Islam and Hossain, 2006). The major coal deposits found in the northwestern Bengal Basin of Bangladesh are all encountered in this Gondwana Group. The quality and characteristic of this coal is very similar to the coal deposits of near by Gondwana basins of India (e.g. Raniganj, Jharia, Jharkhand etc., Norman, 1992). Lithofacies associations in the Gondwana succession of Barapukuria 
Table I. Stratigraphy of the Barapukuria basin, northwestern Bangladesh (Modified after Bakr et al., 1996, Hossain et al., 2013a, b).

\begin{tabular}{|c|c|c|c|c|c|}
\hline Age & Group & Formation & Member & Lithology & $\begin{array}{l}\text { Max. Thickness } \\
\text { (m) }\end{array}$ \\
\hline Holocene & & Alluvium & & Sand, silt and clay & 1.83 \\
\hline Pleistocene & & Barind Clay & & Clay and sandy clay & 10.36 \\
\hline \multirow[t]{2}{*}{ Pliocene } & & Dupi Tila & Upper & $\begin{array}{l}\text { Sandstone, pebbly sandstone } \\
\text { and clay/mudstone }\end{array}$ & 126.82 \\
\hline & & & Lower & $\begin{array}{l}\text { Sandstone, mudstone } \\
\text { and white clay }\end{array}$ & \\
\hline Permian & Gondwana & & & $\begin{array}{l}\text { Feldspathic sandstone, carbona- } \\
\text { ceous sandstone and shale, ferrugi- } \\
\text { nous sandstone, conglomerates, } \\
\text { coal beds }\end{array}$ & 457.32 \\
\hline Precambrian & & $\begin{array}{l}\text { Basement } \\
\text { Complex }\end{array}$ & & $\begin{array}{l}\text { Diorite, granodiorite, quartz diorite, } \\
\text { granite and diorite gneiss }\end{array}$ & $14.32+$ \\
\hline
\end{tabular}

basin suggest that the paleoenvironments changed from fluvio-glacial braided stream, peat-forming backswamp to comparatively low sinuous to moderately sinuous stream channel, and floodplain complexes (Islam and Hossain, 2006).

The Dupi Tila Formationis Pliocene in age and lie directly above the coal bearing Permain Gondwana Group. This group is sub-divided into a sandy Upper Dupi Tila Member and a clayey Lower Dupi Tila Member (Imam, 2013). The contact between the Gondwana Group and the Dupi Tila Formation is erosional. The overlying Braind Clay Formation is also known as Madhupur Clay Formation, which consists mainly of mottled clay, yellowish to reddish brown with ferruginous nodules (Bakr et al., 1996). The Barind Clay Formation is unconformably overlying by alluvium of the Holocene in age consists primarily of sand, silt and clay.

\section{Materials and methods}

Eight fresh coal samples (ca. $100 \mathrm{~g}$ ) were collected using a hand cutter from the coal seam-VI, Barapukuria coal field, Bangladesh (Figs. 2b and 3). Depths of the coal sample points range between 454 and $494 \mathrm{~m}$ from the surface. The coals are dark black to shiny black and brownish in color and brittle structure containing some laminations and chalcopyrite impressions. The coal samples are dried, and subsequent ly powdered using an iron mortar and pestle.
Total organic carbon (TOC), total hydrogen (TH), total nitrogen (TN), and total sulfur (TS) contents were determined by combustion method about $1800^{\circ} \mathrm{C}$ in a CHNS elemental analyzer (EA 1108). Approximately $5 \mathrm{mg}$ of powdered coal sample was placed in a thin Ag film cup, and 1M-HCL added several times and dried at $110^{\circ} \mathrm{C}$ for 30 minutes. The dried coal sample was then wrapped in a thin tin film for combustion. TOC, TH, TN and TS data were calibrated against a BBOT standard (2, 5-Bis-(5-tert-butyl-benzoxazol-2-yl)thiophen), and standard regression line method was employed for quantitative analysis. All analyses were carried out on a dry weight basis at Bangladesh Council of Scientific and Industrial Research (BCSIR) laboratory.

\section{Results and disscution}

Elemental compositions ( $\mathrm{C}, \mathrm{H}, \mathrm{N}$ and $\mathrm{S}$ ) of the studied coal samples are listed in Table II. TOC contents vary from 48 to $75 \mathrm{wt} . \%$, with an average TOC content of $61 \mathrm{wt} . \%$. TH and $\mathrm{TN}$ abundances for the coals range from 3.89 to $5.80 \mathrm{wt} . \%$ (average $4.59 \mathrm{wt} . \%$,) and 2.87 to $3.87 \mathrm{wt} . \%$ (average 3.28 wt.\%), respectively. The coals are characterized by low total sulfur contents and range from 0.19 to $0.37 \mathrm{wt} . \%$ (average $0.30 \mathrm{wt} . \%)$. The TOC to $\mathrm{TN}$ ratio $(\mathrm{C} / \mathrm{N})$ in the coal samples vary between 14 and 21 (average 19) and TOC to C S ratio (C/S) range between 156 and 376 (average 218) (Table II). 
Table II. CHNS elemental analysis (wt.\%) of Permian Gondwana coals in the coal seamVI, Barapukuria coal field, northwestern Bangladesh.

\begin{tabular}{lcccccc}
\hline $\begin{array}{l}\text { Sample } \\
\text { number }\end{array}$ & $\begin{array}{c}\text { TOC } \\
(\%)\end{array}$ & $\begin{array}{c}\text { TH } \\
(\%)\end{array}$ & $\begin{array}{c}\text { TN } \\
(\%)\end{array}$ & $\begin{array}{c}\text { TS } \\
(\%)\end{array}$ & C/N & C/S \\
\hline BCMCL1 & 60 & 4.91 & 3.03 & 0.31 & 20 & 195 \\
BCMCL2 & 62 & 3.89 & 2.91 & 0.29 & 21 & 215 \\
BCMCL3 & 56 & 4.01 & 2.87 & 0.35 & 19 & 159 \\
BCMCL4 & 63 & 4.50 & 3.05 & 0.37 & 20 & 169 \\
BCMCL5 & 75 & 3.91 & 3.79 & 0.20 & 20 & 376 \\
BCMCL6 & 50 & 5.80 & 3.67 & 0.19 & 14 & 265 \\
BCMCL7 & 72 & 4.80 & 3.87 & 0.35 & 19 & 206 \\
BCMCL8 & 48 & 4.92 & 3.01 & 0.31 & 16 & 156 \\
Average & 61 & 4.59 & 3.28 & 0.30 & 19 & 218 \\
\hline
\end{tabular}

\section{Origin of organic matter}

The sources of organic matter within sediments and sedimentary rocks are important in understanding the roles of terrestrial as well as estuarine originated organic matter as sources of energy and nutrients to the terrestrial and marine systems. The origin of organic matter in sedimentary systems is often diverse, as they receive organic matter from both autochthonous and allochthonous sources such as phytoplankton, algae, bacteria, and terrestrial plants (Dale, 1974; Meyers, 1994, 1997). Abundances of TOC in the studied coal samples exhibit wide variation, ranging between 48 and 75 wt.\%, while TN contents are mostly fall between 2.91 and 3.87 wt.\% (Table II). Large variation of TOC in the studied coal seam-VI is likely to be derived from diverse origin of organic matter as well as periodic fluctuation of water tables during accumulation of organic matter in the peat-forming mires (Hossain et al., 2015). Generally, terrestrial plants are consisting of high carbon with low nitrogen (protein) and sulfur, while planktonic organic matters primarily supply nitrogen (Müller, 1977). (Tissot and Welte 1984) reported that higher plants are key organic producer in the terrestrial environment, and consist largely of cellulose and lignin which contain small amounts of nitrogen and sulfur. High TOC content in the coal samples indicate the influence of terrestrial organic matter to the peat bogs. The TOC in the coals show a positive correlation with TN ( $r=0.51$, Fig. 4a), and increase TOC with increasing TN contents, reflecting a comparable source material input to the paleomire.

The $\mathrm{C} / \mathrm{N}$ ratiois widely used to the indicative of sedimentary organic matter, as it is distinguish between algal and terrestrial plant origins of organic matter (Meyers, 1994; Sampei and Matsumoto, 2001; Perdue and Koprivnjak, 2007; Hossain et al., 2009). Terrestrial vascular plants and their derivatives in sediments have $\mathrm{C} / \mathrm{N}$ ratios of greater than 15 (Ertel and Hedges, 1984; Sampei and Matsumoto, 2001) and those of wood, leaf and macrophytee specially high at 209, 28 and 39, respectively (Hedge et al., 1986). Generally, planktonic organic matters deposited in deep-sea sediments contain $\mathrm{C} / \mathrm{N}$ values higher than 10 to 15 (Müller, 1977) owing to the preferential loss of nitrogen relative to carbon (Müller, 1977). Perdue and Koprivnjak (2007) documented that terrestrially derived organic matter is rather depleted in nitrogen abundances. Planktonic organic matters predominantly supply nitrogen, therefore, freshly deposited planktonic organic matter is most reactive for sulfate reduction (Berner, 1984) and have the $\mathrm{C} / \mathrm{N}$ ratio is usually between 6 and 9 (Bordowskiy, 1965). $\mathrm{C} / \mathrm{N}$ ratio of planktonic organic matter in sedimentary environments increases with decomposition rate of the organic matter (Tissot and Welte, 1984). High cellulose and lignin composition of vascular terrestrial plants, along with low protein content, result in $\mathrm{C} / \mathrm{N}$ ratio valueslarger than 15 (Meyers, 1994, 1997; Sampei and Matsumoto, 2001). The $\mathrm{C} / \mathrm{N}$ ratios in the studied coal samples are 20 (BCMCL1), 21 (BCMCL2), 19 (BCMCL3), 21 (BCMCL4), 20 (BCMCL5), 14 (BCMCL6), 19 (BCMCL7), and 16 (BCMCL8), respectively, with mean C/N ratio of 19 (Table II). Most of the coals in the coal seam-VI have $\mathrm{C} / \mathrm{N}$ ratios higher than 15 , suggesting the influx of organic matter is mainly derived from terrestrial higher plants. However, the TOC also show a marked positive correlation with $\mathrm{C} / \mathrm{N}(r=$ 0.70 ), suggests the dominance of vascular plants organic matter input to the peat-forming mire. The coaly organic matter of the Barapukuria basin is likely to be controlled by terrestrial higher plant materials (Farhaduzzaman et al., 2012; Hossain et al., 2013a, 2015). This result is also consistent with the study of tri-aromatic hydrocarbons in Permian Gondwana coals and coaly shales from the Barapukuria basin, Bangladesh and concluded that the presence of substantial amounts of 1,7-dimethylphenanthrene, anthracene and methylanthracene in coals and coaly shales indicating a significant influx of land derived organic matter like coniferous 


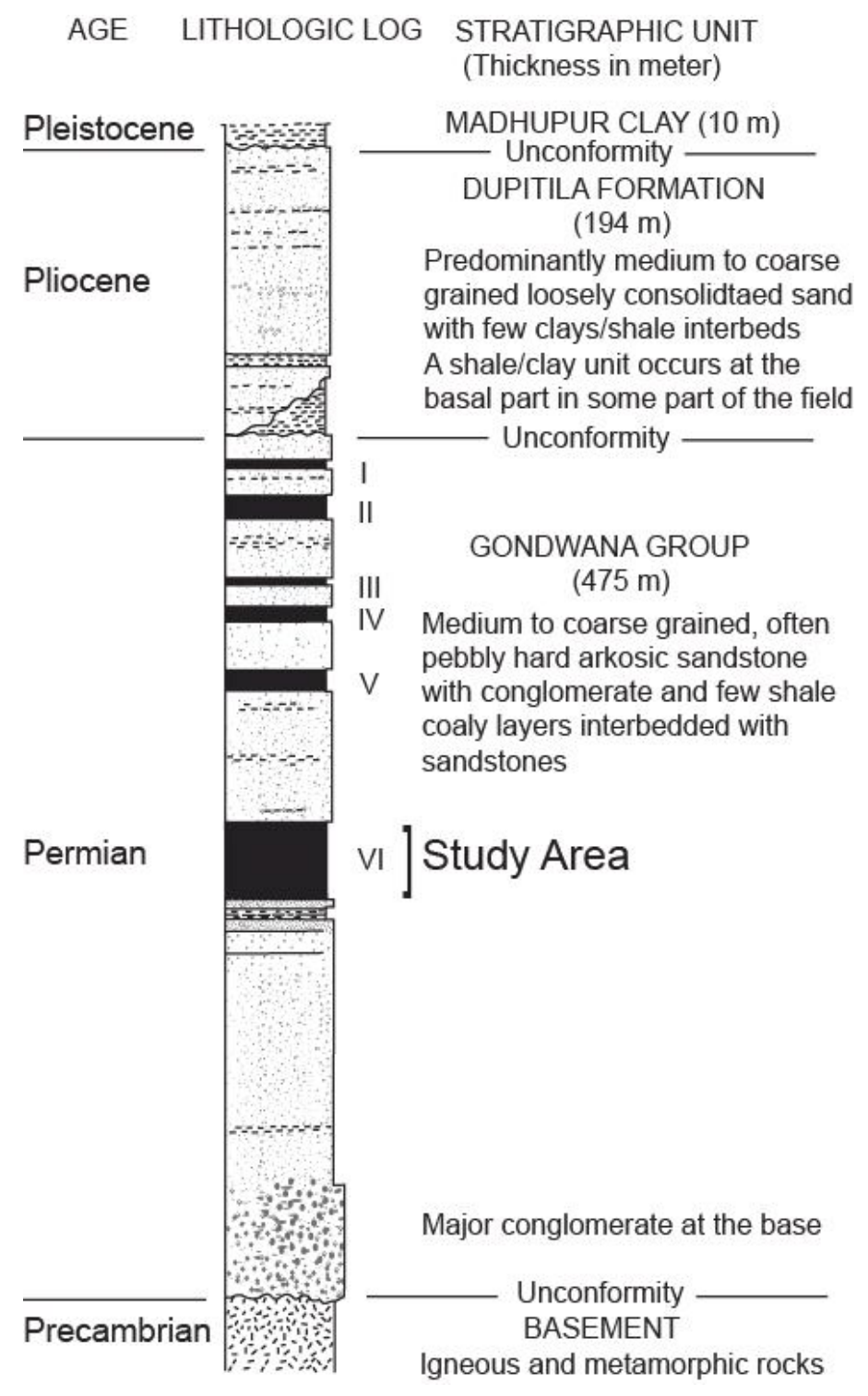

Fig. 3. Summarized lithologic log with major stratigraphic units of the Barapukuria coal field, northwestern Bangladesh (after Imam, 2013)

gymnosperms (Hossain et al., 2013a). On the other hand, high $\mathrm{C} / \mathrm{N}$ ratios $(\geq 12)$ are indicative of low biodegradation, and low $\mathrm{C} / \mathrm{N}$ ratios $(<12)$ are a characteristic of increased bacterial degradation (Hart, 1986). In the present study, C/N ratios fall in the range between 14 and 21 (Table II), reflecting lower degree of biodegradation.

\section{Depositional environments}

In this study, a schematic model has been developed based on relative abundances of TOC, TN, TS and C/S ratio sin order to decipher organic matter depositional environments of coal seam-VI of the Barapukuria basin (Fig. 5). The C/S ratios are widely used as an indicator for inferring depositional conditions of organic matter accumulated in marine or non-marine water-bottom environments (e.g. Berner, 1984; Sampei et al., 1997; Hossain et al., 2009). Since the biogeochemical cycle of sulfur in sediments is in separable from that of carbon, and the relationship depends largely on the depositional environment during or after burial of organic matter. Sediments deposited in marine environment have 

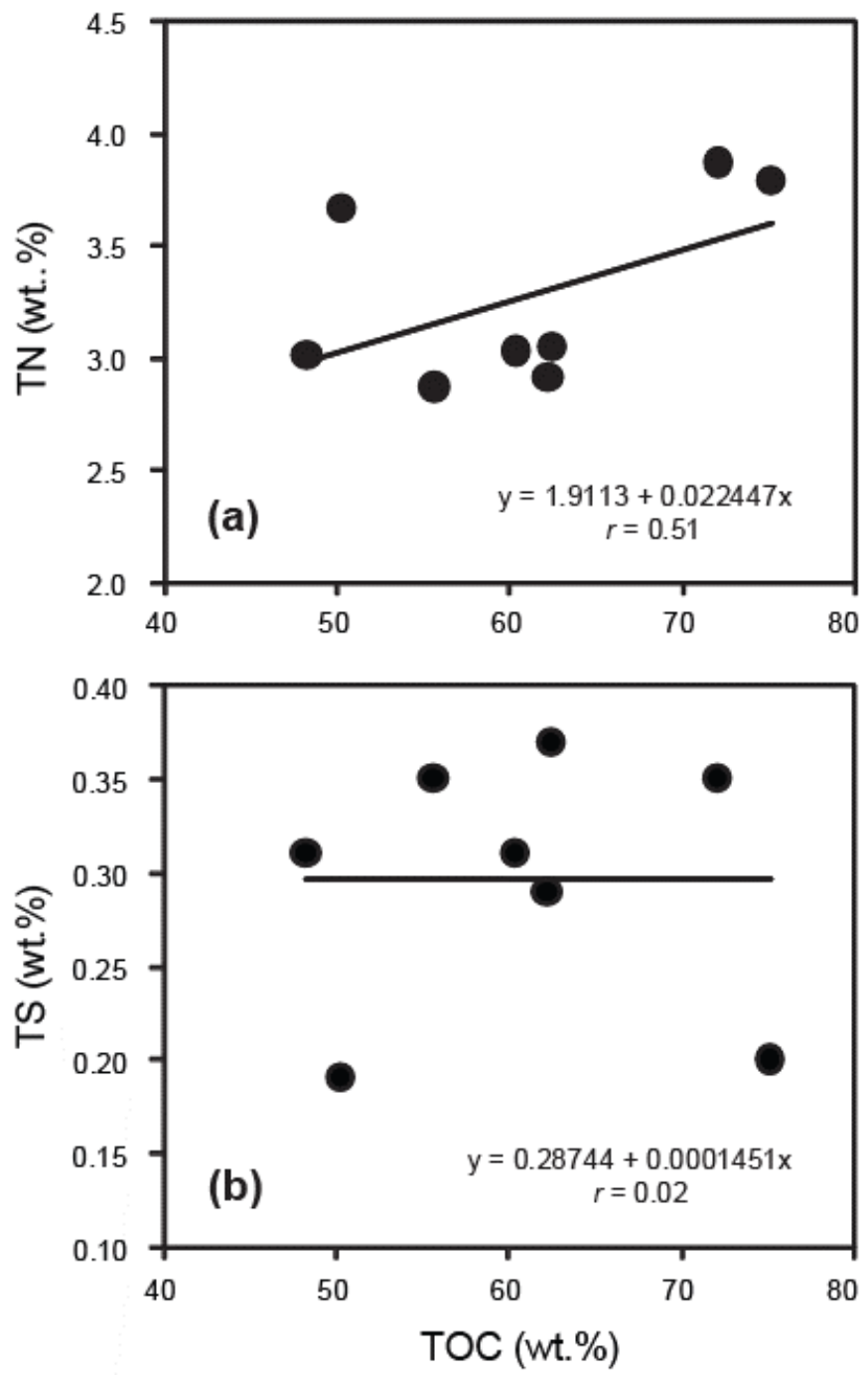

Fig. 4. Variation diagrams of TOC versus TN and TS with correlation coefficients for the Gondwana coals in seam-VI, Barapukuria coal field, north western Bangladesh

low $\mathrm{C} / \mathrm{S}$ values of 0.5 to 5 , whereas freshwater sediments have relatively high $\mathrm{C} / \mathrm{S}$ values $>10$ (Berner and Raiswell, 1984). In the studied coals, sulfur content is relatively low $(<0.5$ wt. \%), with average value of $0.3 \mathrm{wt} . \%$ (Table II), indicates a freshwater influence and suggests that the coaly organic matters in seam-VI were communication with a nonmarine environmental conditions. Kumar et al. (2015) reported that the organic carbon and sulfur contents in the Permian bituminous coal from Jharia coalfield, India vary from 70 to $85 \mathrm{wt} . \%$ (average $76 \mathrm{wt} . \%$ ) and 0.10 to $0.17 \mathrm{wt} \%$ (average $0.14 \mathrm{wt} . \%$ ), respectively with elevated $\mathrm{C} / \mathrm{S}$ ratios of
403 to 704 (average 577). The Jharia coal basin may be attributed to deposition in fluvio-lacustrine environments (Dasgupta, 2005). In addition, Indian Permian coals were accumulated predominantly in swamps of medium wetness conditions (Mishra, 1996). However, TOC in this study show no correlation and scatter distribution with TS ( $\mathrm{r}=$ 0.02, Fig. 4b). Some coal samples contained relatively slight elevated TS and low TOC contents (Table II). This sulfur probably considers inland lake environment and/or brackish coastal lakes with swamps, and perhaps the cyclic variation of climate over the region. However, presence of minor terrestrial palynomorp hacritarch (e.g. Circulisporites, Peltacystia, Haplocystia, Leiosphaeridia) in coal seam-VI signifi esinland basin with brackish water influence (Islam et al., 2003; Hossain et al., 2015). On the other hand, increases in sulfur accumulation in lakes may be due ultimately to changing organic producers and/or decline to the sediment or water column from anoxic to oxic conditions (Peters, 1986). This interference is ascribed to be different sulfur sources input to the paleomires or possibly least bacterial degradation under oxic or anoxic events. Amijaya and Littke (2005) suggested that low sulfur content in coal is well known forrestricted sulfur input and / orabsence of sulfate-reducing bacteria in acidic conditionsduring organic matter deposition in peat-bogs.Accordingly, high sulfur content in organic mattertypically indicate marine environment where high amount of sedimentary pyrite deposit occurred (Tissot and Welte, 1984). The pyrite content in the studied coals is less abundant, implying that sulfate reducing bacterial activity to the paleomire was rather low. Freshwater lakes often describe the characteristics of vascular plant and planktonic organic matter inputs, where the sulfate levels are enormously low (Sampei et al., 1997). Furthermore, bacterial activity in marine and lake sediments is dominated by sulfate reducers, and the sulfur content is relatively higher in marine water than in freshwater (Hughes et al., 1995). C/S ratios in the coals vary from 156 to 376 (Table II), indicate that the depositional environment of the coal seam-VI is characterized by dominantly freshwater lake/swamp. In addition to the relatively high $\mathrm{C} / \mathrm{S}$ ratios in Gondwana coaly shales occurs at thick coal seam-VI, Barapukuria basin support the inference of a freshwater lacustrine environment during organic matter preservation (Hossain et al., 2015). Hossain et al. (2015) also mentioned that lower part of the Gondwana succession was accumulated in dominantly oxic conditions with abun- 


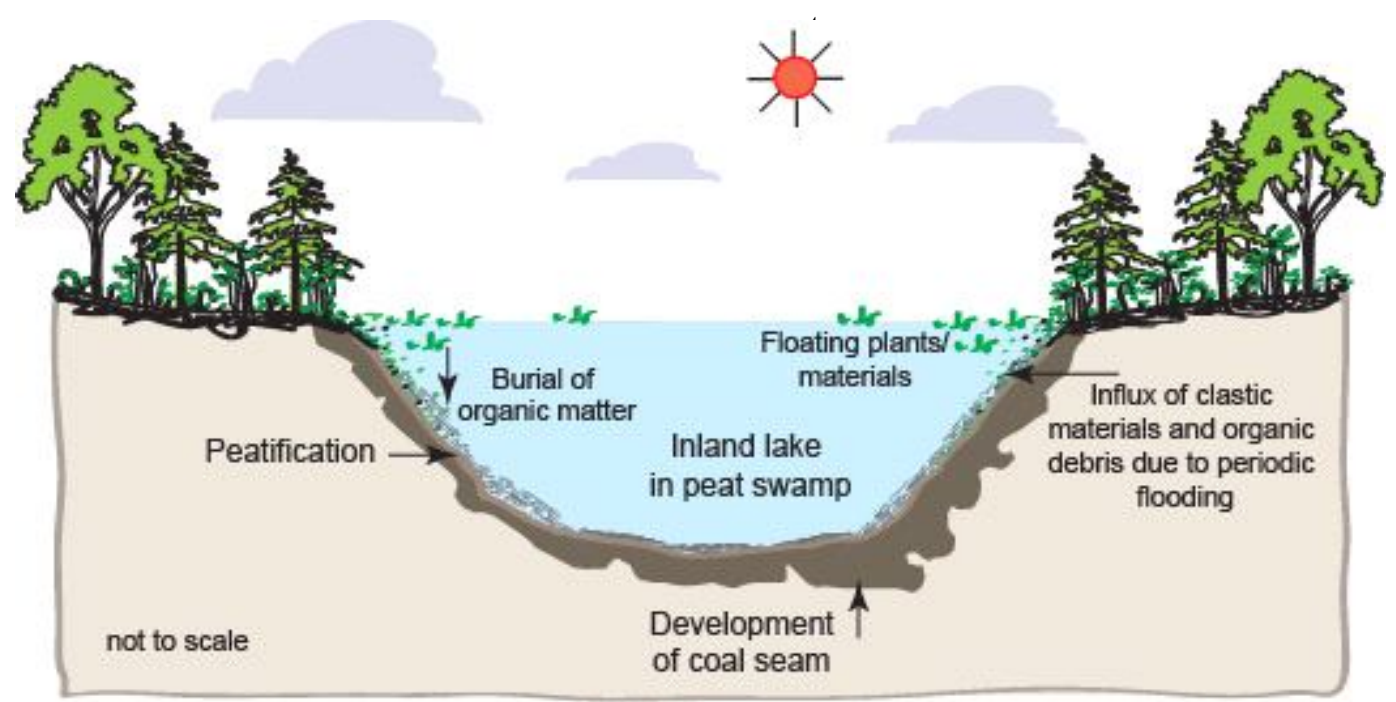

Fig. 5. Schematic diagram for deposition of coal seam-VI, Barapukuria coal field, northwestern Bangladesh

dant input of terrestrial derived organic matter. Plant production is relatively high in areas of hot humid climatic conditions and is rather low in dry/cool climatic conditions. Largescale swamps are normally connected with some sorts of rivers and lakes in arid or seasonally dry regions of the globe. Islam and Hossain (2006) stated that low- to moderately-sinuous stream channel is commonly associated with peat-forming mire complexes in the Gondwana Barapukuria basin. Organic matter in the channel sediments has normally high $\mathrm{C} / \mathrm{N}$ ratios and substantially low sulfur contents (Hart, 1994). The low- to moderately-sinuous stream channel exhibits the inland lake or brackish coastal lakes environments, where the organic matter normally reflecting freshly deposited least planktonic matter with high contributions of terrestrial plants (Sampei et al., 1997). Additionally, the abnormally thick coal seam-VI in the present study contained thin layers of clastic sediments. The clastic sediments in the coal seam are interpreted as fluvial origin. Therefore, the elemental compositions and ratio values suggest that the organic matter in the thick coal seam-VI, Barapukuria basin might be originated from higher land plants, and preserved in a diverse array of inland lake environments under fluvial regime.

\section{Conclusion}

Eight Gondwana coal samples of Permian age were collected from coal seam-VI of the Barapukuria coal field, north-
Bangladesh have been investigated using CHNS elemental analysis to identify sources and depositional environments of organic matter. TOC, TN, TH and TS contents of the coal samples were ranging from 48 to $75 \mathrm{wt} \%$ (average $61 \mathrm{wt} . \%$ ), 3 to 4 wt.\% (average $3 \mathrm{wt} . \%$ ), 4 to $6 \mathrm{wt} . \%$ (average $5 \mathrm{wt} . \%$ ) and 0.19 to $0.37 \mathrm{wt} . \%$ (average $0.30 \mathrm{wt} . \%$ ), respectively. The $\mathrm{C} / \mathrm{N}$ and $\mathrm{C} / \mathrm{S}$ ratio values range from 14 to 21 (average 19) and 156 to 376 (average 218), respectively suggesting land plant derived organic matter subsequently deposited in entirely terrestrial environments.

\section{Acknowledgment}

Authors gratefully acknowledge to BCMCL (Barapukuria Coal Mining Company Limited) for provided coal samples and supply of printed materials. We would like to thank BCSIR (Bangladesh Council of Scientific and Industrial Research) for CHNS analytical facilities. Finally, we also thank to Dr. Sarwar Jahan and an anonymous reviewer for constructive suggestions to improve this manuscript considerably.

\section{References}

Amijaya H and Littke R (2005), Microfacies and depositional environment of Tertiary Tanjung Enim low rank coal, South Sumatra Basin, Indonesia. Int. J. Coal Geol. 61: 197-221. 
Bakr MA, Rahman QMA, Islam MM, Islam MK, Uddin MN, Resan SA, Halder MJ, Islam MS, Ali MW, Chowdhury MEA, Mannan KH and Anam ANMH (1996), Geology and coal deposits of Barapukuria Basin, Dinajpur district, Bangladesh. Rec. Geol. Surv. Bangladesh 8: 42.

Berner RA (1984), Sedimentary pyrite formation: an update. Geo chim. Cosmochim. Acta 48: 605-615.

Berner RA and Raiswell R (1984), C/S method for distinguishing freshwater from marine sedimentary rocks. Geology 12: 365-368.

Bordowskiy OK (1965), Source of organic matter in marine basins. Mar. Geol. 3: 5-31.

Dale NG (1974), Bacteria in intertidal sediments: factors related to their distribution. Limnol. Oceanogr. 19: 509-518.

Dasgupta P (2005), Facies pattern of the middle Permian Barren Measures Formation, Jharia basin, India: The sedimentary response to basin tectonics. J. Earth Syst. Sci. 114: 287-302.

Ertel JR and Hedges JI (1984), The lignin component of humic, fulvic, and base-insoluble fractions. Geochim. Cosmochim. Acta 43: 2065-2074.

Farhaduzzaman M, Wan Hasiah A and Islam MA (2012), Depositional environment and hydrocarbon source potential of the Permian Gondwana coals from the Barapukuria Basin, Northwest Bangladesh. Int. J. Coal Geol. 90-91: 162-179.

Hart G.F (1986), Origin and classification of organic matter in clastic systems. Palynology 10: 1-23.

Hart GF (1994), Maceral palynofacies of the Louisiana deltaic plain in terms of organic constituents and hydrocarbon potential. In: Traverse, A. (Ed.) Sedimentation of organic particles: Cambridge University Press, p. 141-176.

Hedges JI, Clark WA, Quay PD, Richey JE, Devol AH and Santos UM (1986), Compositions and fluxes of partic- ulate organic material in the Amazon River. Limnol. Oceanogr. 31: 717-738.

Hossain HMZ, Sampei Y and Roser BP (2009), Characterization of organic matter and depositional environment of Tertiary mudstones from the Sylhet Basin, Bangladesh. Org. Geochem. 40: 743-754.

Hossain HMZ, Sampei Y, Hossain QH, Roser BP and Islam MSU (2013a), Characterization of alkyl phenanthrene distributions in Permian Gondwana coals and coaly shales from the Barapukuria Basin, NW Bangladesh. Res. Org. Geochem. 29: 17-28.

Hossain HMZ, Sampei Y, Hossain QH, Roser BP and Islam MSU (2013b), Kerogen type and hydrocarbon generation potential of Permian Gondwana coal, NW Bengal Basin, Bangladesh. ICEIRE 2013, 1091-1096.

Hossain HMZ, Sampei Y, Hossain QH and Roser BP (2015), Organic geochemical characterization of Carboniferous-Permian Gondwana coaly shales intercalated in coals/sands of the Barapukuria basin, Bangladesh. Org. Geochem. (Submitted, under review).

Hughes WB, Holba AG and Dzou LIP (1995), The ratios of dibenzothiophene to phenanthrene and pristane to phytane as indicators of depositional environment and lithology of petroleum source rocks. Geochim. Cosmochim. Acta 59: 3581-3598.

Hussain MM and Curtin GC (1995), Results of petrographic studies and chemical analyses of the crystalline drill cores from the Barapukuria area, Parbatipur Thana, Dinajpur District, Bangladesh. Rec. Geol. Surv. Bangladesh 7(5): $42 \mathrm{p}$.

Imam B (2013), Energy Resources of Bangladesh. Second edition, University Grant Commission, Bangladesh, $324 \mathrm{p}$.

Islam MS, D'Rozario A, Chowdhury KR and Banerjee M (2003), Palynostratigraphy of the Gondwana sequence in the Barapukuria Basin, Bangladesh. Bangladesh Geosci. J. 9: 1-29. 
Islam MR and Hayashi D (2008), Geology and coal bed methane resource potential of the Gondwana Barapukuria coal basin, Dinajpur, Bangladesh. Int. J. Coal Geol. 75: 127-143.

Islam MS and Hossain I (2006), Lithofacies and Embedded Markov Chain analyses of Gondwana sequence in boreholes GDH-40 and 43, Barapukuria coal field, Bangladesh. Bangladesh J. Geol. 25: 64-84.

Kumar H, Mishra S, Mishra MK and Parida A (2015), Petrographical characteristics of bituminous coal from Jharia coal field India: It's implication on coal bed methane potentiality. Pro cedia Earth Planet. Sci. 11: 38-48.

Meyers PA (1994), Preservation of source identification of sedimentary organic matter during and after deposition. Chem. Geol. 144: 289-302.

Meyers PA (1997), Organic geochemical proxies of paleoceanographic, paleolimnologic, and paleoclimatic processes. Org. Geochem. 27: 213-250.

Mishra HK (1996), Comparative petrological analysis between the Permian coals of India and Western Australia: paleoenvironments and thermal history. Palaeogeogr. Palaeoclimatol. Palaeoecol. 125: 199216.

Müller PJ (1977), C/N ratios in Pacific deep-sea sediments: Effect of inorganic ammonium and organic nitrogen compounds absorbed by clays. Geochim. Cosmochim. Acta 41: 765-776.
Norman PS (1992), Evaluation of the Barapukuria coal deposit NW Bangladesh. In: Annels AE (Ed.), Case histories and methods in mineral resource evaluation. Geol. Soc. Spec. Publ. 63: 107-120.

Perdue EM and Koprivnjak JF (2007), Using the C/N ratio to estimate terrigenous inputs of organic matter to aquatic environments. Estuar. Coast. Shelf Sci. 73: 6572 .

Peters KE (1986), Guidelines for evaluating petroleum source rock using programmed pyrolysis. $A A P G$ Bulletin 70(3): 318-329.

Sampei Y and Matsumoto E (2001), C/N ratios in a sediment core from Nakaumi Lagoon, southwest Japan-usefulness as an organic source indicator. Geochem. J. 35: 189-205.

Sampei Y, Matsumoto E, Kamei T and Tokuoka T (1997), Sulfur and organic carbon relationship in sediments from coastal brackish lakes in the Shimane peninsula district, southwest Japan. Geochem. J. 31: 245-262.

Tissot BP and Welte DH (1984), Petroleum Formation and Occurrence, $2^{\text {nd }}$ Ed. Springer Verlag, Berlin.

Ward CR (1984), Coal Geology and Coal Technology. Blackwell.

Wardell-Armstrong Ltd. (1991), Techno-economic feasibility study, Barapukuria coal project, Dinajpur, Bangladesh, 12 volumes. Report submitted to Ministry of Energy and Mineral Resources, Government of People's Republic of Bangladesh (unpublished).

Received:14 January 2015; Revised: 03 March 2016; Accepted: 24 April 2016. 